\title{
A IMAGEM DA CAPA: DUALIDADE EM CAPA
}

E

m resumo, o desenho da capa visa trazer uma reflexão acerca da sociedade do consumo, como evoluímos e conversamos com o entorno, tendo no Design como bússola, dando conta de uma alusão paralela ao desenvolvimento do ser humano.

Emoção, prazer, afeto e satisfação dão conta de sentimentos relativos com prazer e felicidade. Por meio da imagem surge uma alegoria para explicitar, desde meios de produção em série até o rigor técnico relacionado com padrões internacionais. Já em outro extremo o sentido cultural existente dentro do consumo ganha destaque, seja em um métier artesanal ou industrial.

O consumo, como campo de pesquisa, também se congrega em estudos de gênero, idade e demais padrões que permitem tecer todo o espectro cromático do tecido social. Aqui, em detalhe na capa por meio da distinção das formas humanas, reside uma denotação perfeita para explorar o sentido de autoidentidade, donde emerge o aspecto temporal que contém todos nós - afinal somos residentes e filhos do tempo presente. Dele manifestam-se costumes hábitos, crenças e valores que, por vezes, assumem configurações pictóricas.

Os primeiros acordes dessa nova abordagem também foram sentidos no campo do Design - contendo nele moda, consumo, experiências e representações gráficas - se fizeram ouvir no Brasil 1994, quando Alexander Manu, em palestra intitulada "Forms Follows Spirit", atentou que, por criar objetos físicos os designers costumam pensar apenas em formas tangíveis e satisfação mecânica dos usuários. Anos adiante, revendo a trajetória do Design a partir da era industrial, Klaus Krippendorff (2001) adiciona que o Design centrado no ser humano é, ao seu modo de ver, interpretar e conviver com o entorno. O mesmo pesquisador teceu novas linhas para essa trama, conforme segue: "Não reagimos às qualidades físicas das coisas, mas o que elas significam para nós". Klaus Krippendorff (2001)

Os relacionamentos entre os traços do código de barra e das figuras humanas visa dar conta do sentido da experiência social do consumo. Daqui, em sua forma mais pura, o sentido de experiência pode ser visto conforme, Forlizzi \& Ford (2000), sendo um fluxo constante que ocorre durante momentos de consciência. Aqui pode-se considerar os seguintes aspectos: instrumental, não-instrumental e mesmo não-física. Ademais, às experiências ocorrem simultaneamente, em um emaranhado emoções, tendo aspectos dinâmicos (Jaasko et al, 2003). Elas funcionam como containers de uma infinidade de experiências menores (Forlizzi \& Ford, 2000). Assim, a antecipação e a lembrança de experiências geram outras em um ciclo repetitivo. Dando conta do mesmo ritmo cíclico o projeto da capa tende por meio do conjunto de traços em alturas diferentes, formular uma dança que leve o leitor ao caminhar frenético de uma passarela de moda ou de uma vista impossível, contando com o olhar do manequim, em um a vitrine de shopping, em direção para todos "os consumidores platônicos" que poderiam despir de suas vestes. Por este movimento à peça de roupa transitaria entre corpos; de um inanimado para outro em movimento. 
Por fim, recorda-se de Helander \& Tham (2004), ao definirem Hedonomia, oriunda do grego Hedonomos, significando prazer; e Nomos, significando leis, princípios. Tendo na ênfase desta disciplina toda promoção do prazer na relação das pessoas com os sistemas cotidianos. O desenho, pelas suas partes, representa algumas profissões por meio dos artefatos utilizados por pessoas na base da figura, enquanto o código de barras referenda-se aos sistemas de organização e produção social. E, em última instância, o conjunto de cores exalta nossas diferenças em quaisquer escalas - individuais ou continuais, conforme os símbolos em cores das bandeiras confirmam. Em suma, dele pode-se elicitar toda dicotomia humana, presente em tempos de felicidade instantânea, fria e seriada.

\section{Eduardo Ariel de Souza Teixeira}

KRIPPENDORFF, Klaus. 2001. Design centrado no ser humano: uma necessidade cultural. In: Estudos em Design. Rio de Janeiro: Associação de Ensino de Design do Brasil. v.8, n.3, 87-98. 